\title{
Effects of citrox treatment on the survival of Methicillin-Resistant Staphylococcus aureus (MRSA) in chicken fillets packed under vacuum
}

\author{
Hany Mohamed YEHIA ${ }^{1,2 *}$, Abdulrahman Hamad AL-MASOUD ${ }^{1}$, Omer Nasser ALSAWMAHI ${ }^{1}$, \\ Amani Hamzah ALJAHANI ${ }^{3}$ (D), Mohamed Ferkry Serag EL-DIN ${ }^{1,4}$
}

\begin{abstract}
Citrox has natural antibacterial effect against many foodborne pathogens and contaminated bacteria. It mainly contains citric acid, ascorbic acid, and malic acid. We studied the antimicrobial effects of citrox solution ( $1 \%$ and $2 \%)$ on the total viable count of methicillin-resistant Staphylococcus aureus (MRSA) on chicken meat fillet. The samples were treated with $10^{6} \mathrm{CFU} / \mathrm{g}$ of meat, vacuum-packed (VP), and $4{ }^{\circ} \mathrm{C}$ for $3,6,9,12,15,18,21$ days. We have also studied the effect of citrox on the total volatile basic nitrogen (TVBN) content and $\mathrm{pH}$ changes during the storage periods. The results revealed that citrox inhibited the growth of methicillin-resistant $S$. aureus (MRSA), in the chicken fillet. The total viable count of MRSA gradually decreased in all treated samples that were stored at $4{ }^{\circ} \mathrm{C}$ about $2 \log$ cycle than Chicken-Staph groups after $3,6,9$, and 12 days and about $1 \log$ cycle than Chicken-Salt group after 3,6, and 9 days of storage. Total volatile base nitrogen (TVB-N) were observed to be reduced in Chicken- Citrox-treated samples stored at $4{ }^{\circ} \mathrm{C}$ than Chicken-Staph, and Chicken-Salt treated samples. The results indicated that citrox is effective to reduce the total count of $S$. aureus (MRSA) in the first three days of storage by a reduction in the number of bacteria $1 \log$ cycle.
\end{abstract}

Keywords: citrox; chicken; Methicillin-Resistant Staphylococcus aureus (MRSA); Total Volatile Base Nitrogen (TVBN); pH.

Practical Application: Control of Methicillin-Resistant Staphylococcus aureus (MRSA) in chicken fillets using citrox.

\section{Introduction}

Methicillin-resistant Staphylococcus aureus (MRSA) was identified in 1962 and, together with certain species of Enterococcus, is currently considered as a global pandemic threat (Centers for Disease Control and Prevention, 2013; Rossolini et al., 2014). There are three groups of methicillin-resistant S. aureus - Healthcare-associated, methicillin-resistant $S$. aureus (HA-MRSA) and considered as a major causative agent as chronic diseases and presence of a catheter among others, then after two decades the first case of acquired community-associated S. aureus MRSA (CA-MRSA) was reported in many countries (Deurenberg et al., 2007), in community-level studies, the CA-MRSA carriage prevalence among the general public ranged from $0 \%$ to $23.5 \%$, whereas that ranged from $0.7 \%$ to $10.4 \%$ in hospital settings (Wong et al., 2018), and Livestock-associated S. aureus (LA-MRSA), has also been reported to be associated with companion animals (Nemati et al., 2008; European Food Safety Authority, 2009; Wendlandt et al., 2013; Vincze et al., 2014). Dweba et al. (2019), stated that, Virulent and multidrug resistant $S$. aureus including MRSA isolates were detected in South African livestock production systems as well as their environments. The HA-MRSA and CA-MRSA that generally affect humans are not involved in livestock infections. However, LA-MRSA may affect humans, especially in the case of occupational contact with livestock (Cuny et al., 2015). Though many foods containing CA-MRSA, LA-MRSA, and even HA-MRSA, have been documented, however, it is not clear whether the MRSA can be classified as food-borne pathogens. MRSA is found in several species of animals and their meat products, such as pigs (Khanna et al., 2008; Smith et al., 2009), poultry (Nemati et al., 2008), and cattle (Hasman et al., 2010). de Boer et al. (2009), found MRSA predominantly in turkey (35.3\%), followed by chicken (16.0\%), veal (15.2\%), pork (10.7\%), and beef (10.6\%). Boost et al. (2013), recovered MRSA from chicken samples of 455 and found positive to 31 as a ratio of $6.8 \%$ in both fresh and frozen chicken (31/455). Many studies have reported the S. aureus infections in poultry: Andrew et al. (2011), reported that $52 \%$ occurrence of multidrug-resistant $S$. aureus in the US meat and poultry. Poultry meat is highly perishable and provides a high nutritive medium for the growth of bacteria like spoilage and pathogenic microorganisms (Vasilatos \& Savvaidis, 2013). The increasing productivity and global demand for poultry meat also increased the importance of poultry meat hygiene and safety worldwide (Sofos \& Geornaras, 2010).

Total volatile basic nitrogen (TVBN) is considered as a major chemical parameter related to microbial growth and contaminations of meats and fish (Fraqueza et al., 2008; Boziaris et al., 2011). The TVBN in dark turkey meat packed under aerobic condition has been shown to relate well with the microbial growth of spoilage microorganisms (Fraqueza et al., 2008). The other parameter related to the microbial growth is the changes in $\mathrm{pH}$ (Gram \& Dalgaard 
2002, Boziaris et al., 2011). These two factors are considered important indicators of microbial spoilage in meat and poultry (Hernández-Herrero et al., 1999; Fraqueza et al., 2008).

Preservation of chicken and its products is based mainly on the high acidity of the preservatives employed to inhibit the growth of spoilage and pathogenic microorganisms. However, their use is considered undesirable by consumers, are demanding reduced levels of such additives in foods. Although the safety of these additives is supposed to be ensured primarily by their low $\mathrm{pH}$, several pathogens, namely E. coli O157: H7, L. monocytogenes, and Salmonella spp., have been reported to survive or even grow in these foods (Smittle, 2000). Usually, the carriers of the pathogen are the raw ingredients, as well as any contamination from the processing environment and packaging operations.

Therefore, the present study was aimed to evaluate the effect of citrox at the different concentration 1 and $2 \%$ on methicillin-resistant $S$. aureus (MRSA) in vitro. Moreover, its effect on the survival, and elimination of the bacterial growth for prolonging the shelf life of vacuum packaged (VP) chicken fillets stored at $4{ }^{\circ} \mathrm{C}$ for $0,3,6,9,12,15,18$, and 21 days were studied. The study was also aimed to determine the changes in total volatile basic nitrogen (TVBN) and $\mathrm{pH}$ during the storage periods.

\section{Materials and methods}

\subsection{Sample preparation}

Chicken fillet samples (skinless and boneless), approximately weighing $25 \mathrm{~g}$, were collected from the retail markets for poultry located in Riyadh, Saudi Arabia. The samples were incubated at $2{ }^{\circ} \mathrm{C}$ to be used in further experimental steps.

\subsection{Bacterial strains}

The methicillin-resistant strains of $S$. aureus (MRSA) obtained from the laboratory of food microbiology, College of Food Science, King Saud University were used as inoculum $\left(10^{6} \mathrm{CFU} / \mathrm{mL}\right)$. For activation of the strain, $1 \mathrm{~mL}$ of of overnight culture was added to $9 \mathrm{~mL}$ of Brain heart infusion broth (HIMEDIA, M210-500G), and incubated at $37^{\circ} \mathrm{C}$ for $24 \mathrm{~h}$. Subsequently, the samples were centrifuged to collect the sediments, which was then washed twice with saline solution $(0.85 \% \mathrm{NaCl})$ before preparation of the final solutions.

\subsection{Preparation of citrox solution}

The citrox solution was prepared by mixing $18 \mathrm{~g}$ citric acid, $18 \mathrm{~g}$ malic acid, and $5 \mathrm{~g}$ ascorbic acid in $100 \mathrm{~mL}$ of water. The $\mathrm{pH}$ of the solution was adjusted to $\sim 2.7$. It was yellow color. The citrox solution was subsequently diluted to $1 \%$ and $2 \%$ and sterilized at $121{ }^{\circ} \mathrm{C}$ for $15-20$ mins along with $\mathrm{NaCl} 0.85 \%$.

\subsection{Chicken fillet inoculation, treatment, and packaging}

According to Vardaka et al. (2016) with some modifications, five hundred twelve chicken fillet samples (approximately weighing $25 \mathrm{~g}$, each) were divided into three main groups A, B, C and D (each containing 128 samples).
Group A, Chicken-Salt: The samples were soaked in a tray containing $1 \mathrm{~L}$ of salt solution $(0.85 \%, \mathrm{NaCl})$ and left for 2 mins. This has been used as the negative control.

Group B, Chicken-Salt-Staph: The samples were soaked in $1 \mathrm{~L}$ of saline solution and then drained through a sterilized sieve. Subsequently, the samples were soaked in methicillin-resistant S. aureus (MRSA) inoculum $\left(10^{6} \log \mathrm{CFU} / \mathrm{mL}\right)$ and left for 2 mins. This has been used as a positive control.

Group C and D, Chicken-Salt-Staph-Citrox 1\% and 2\%: The samples were soaked in $1 \mathrm{~L}$ of saline solution for $2 \mathrm{mins}$, followed by soaking in methicillin-resistant S. aureus (MRSA) for another 2 mins. Subsequently, $1 \mathrm{~L}$ of citrox solution (final concentration $1 \%$ and $2 \%$ in the salt solution for group $\mathrm{C}$ and $\mathrm{D}$, respectively) was added after draining the samples through a sieve. All samples left on the sieve until dried before packing in transparent polyethylene pouches (low density) and sealed under vacuum (Plas Vac 20, Komet, Germany), and finally stored in cooled incubators at $4{ }^{\circ} \mathrm{C}$ for different intervals of time $0,3,6,9,12,15,18$, and 21 days.

The samples were repeated for determination of TVBN, $\mathrm{pH}$ and sensory test.

\subsection{Antimicrobial activity of citrox}

The antimicrobial effect of citrox on methicillin-resistant S. aureus (MRSA) was evaluated by inoculating one colony of S. aureus in Brain heart infusion broth (HIMEDIA, M210) at $37^{\circ} \mathrm{C}$ for $24 \mathrm{~h} .100 \mu \mathrm{l}$ of culture $\left(10^{6} \mathrm{CFU} / \mathrm{mL}\right)$ was inoculated to Brain heart infusion medium (Oxoid, CM375) using the Agar well diffusion method. Then, a hole with a diameter of $6 \mathrm{~mm}$ was punched aseptically with a sterile cork borer, and two different volumes of ( $50 \mathrm{~mL}$ and $100 \mathrm{~mL}$ ) $1 \%$ and $2 \%$ citrox solution were introduced into the well. Then, the plates were incubated at $37^{\circ} \mathrm{C}$ for $24 \mathrm{~h}$, and the zone of inhibition was observed.

\subsection{Microbiological analyses}

Chicken fillet samples (10 g) were aseptically transferred to $90 \mathrm{~mL}$ of $0.1 \%$ peptone water (Oxoid, CM 0009) in a stomacher bag (Seward Ltd, London, UK), and the mixture was homogenized for $1 \mathrm{~min}$ at room temperature. For enumeration of methicillin-resistant $S$. aureus, $0.1 \mathrm{~mL}$ and $0.01 \mathrm{~mL}$ samples of the dilution (1/10) were poured into the Brain Heart Infusion medium (Oxoid, CM375) and incubated at $37^{\circ} \mathrm{C}$ for $24-28 \mathrm{~h}$.

\subsection{Chemical analysis}

\subsubsection{Determination of Total Volatile Base Nitrogen (TVBN)}

For determination of total volatile base nitrogen, method of magnesium oxide was used as described by Association of Official Analytical Chemists (1990) as follows: $5 \mathrm{~g}$ of sample was added to the heating flask containing $300 \mathrm{~mL}$ distilled water plus $2 \mathrm{~g}$ magnesium oxide and anti-foaming granules. In the receiving flask, $25 \mathrm{~mL}$ of boric acid (2\%), with a few drops of Tashiro indicator $(1.25 \mathrm{~g}$ methyl red $+0.32 \mathrm{~g}$ methylene blue in liter ethanol 90\%) was added. The two flasks (heating \& receiving) were connected to the evaporator, and the water bath 
was managed. After 25 minutes, the distillation was stopped. The content of the receiving flask was titrated to the endpoint using sulphuric acid $(0.05 \mathrm{~N})$.

The total volatile nitrogen was determined as follows:

$$
\mathrm{TVBN}=(\mathrm{V} \times \mathrm{N} \times 100 \times 14) / \mathrm{W}
$$

Where: $\mathrm{V}=$ volume $(\mathrm{mL}) \mathrm{H}_{2} \mathrm{SO}_{4}$ used for the sample. $\mathrm{N}=$ normality of $\mathrm{H}_{2} \mathrm{SO}_{4}(0.05 \mathrm{~N})$.

$\mathrm{W}=$ weight of sample in gram.

\subsection{2 pH measurement}

To measure the $\mathrm{pH}, 25 \mathrm{~g}$ of each sample was added to $10 \mathrm{~mL}$ of distilled water and homogenized for $1 \mathrm{~min}$. The $\mathrm{pH}$ measurement was performed using a $\mathrm{pH}$ meter ( $\mathrm{pH} 8000$ - Sargent-Welch, Warner Road, Cleveland, Ohio, U.S.A) in triplicates.

\subsubsection{Color measurement}

The surface color of the chicken samples was measured by $\mathrm{CIEL}^{*} \mathrm{a}^{\star} \mathrm{b}^{\star}$ color scales based on the opponent color theory. This theory assumes that the receptors in the human eye perceive color as the following pairs of opposites. L scales (0-50): light vs. dark where a low number indicates dark and high number indicates light. A scale: red vs. green where a positive number indicates red and a negative number indicates green. B scale: Yellow vs. blue, where a positive number indicates yellow, and a negative number indicates blue. The samples were evaluated during the storage period using a colorimeter (Spectrophotometer, Spectrophotometer, CR-300, Minolta Inc., Japan) which was calibrated against a black and white reference tiles. Measurements of $L^{*}, a^{*}$, and $b^{*}$ values of each treatment were recorded at three different locations, each with three replications.

\subsection{Sensory test}

Chicken fillet samples were cooked using a microwave oven (Sanyo, Model: EM-G1299V, China) at high power for $10 \mathrm{~min}$. A panel of five experienced food scientists (technicians, member staff, and postgraduate students) was selected to evaluate the sensory attributes of cooked chicken. All the panelists had previously participated in training sessions to become familiar with the sensory characteristics of cooked chicken. Taste, odor, and appearance of the cooked chicken fillets were used as the testing parameters to evaluate the samples. Acceptability of odor and taste was estimated using a scale ranging from 0 to 9 . The panel was asked to indicate whether the products had an acceptable or unacceptable (deviating) taste, flavor, and odor. A 9-point hedonic scale was used (9=like extremely, 5=like moderately, $1=$ dislike extremely) in this study.

\subsection{Statistical analysis}

All the results were represented as Mean $(\mathrm{M}) \pm$ standard deviation $(M \pm S D)$. Analysis of variance among the groups and periods of storage were analyzed using a completely randomized factorial design (SAS Institute Inc, 1988). When a significant main effect was detected, the means were separated with Duncan multiple tests (Duncan, 1955). Differences between groups with $\mathrm{p} \leq 0.05$ were considered significant.

\section{Results and discussion}

Inoculation of Citrox $1 \%$ and $2 \%$ solutions inhibited the growth of MRSA. However, the zone of inhibition was observed to be larger, with $2 \%$ citrox (Figure 1). Since both concentrations were effective, we decided to treat the chicken fillets with both to limit or stop the growth of MRSA in chicken fillet samples during the storage period.

\subsection{Total viable count}

The total viable count (TVC) that estimates the concentration of microorganisms in a sample is commonly used as a microbiological parameter. It determines the hygiene status, and shelf life of meat and meat products. The total viable counts in chicken fillets during the 21 days of storage are presented in Figure 2. The chicken samples injected with MRSA (the positive control) recorded highest total viable count of $8.200 \mathrm{log} \mathrm{CFU} / \mathrm{g}$

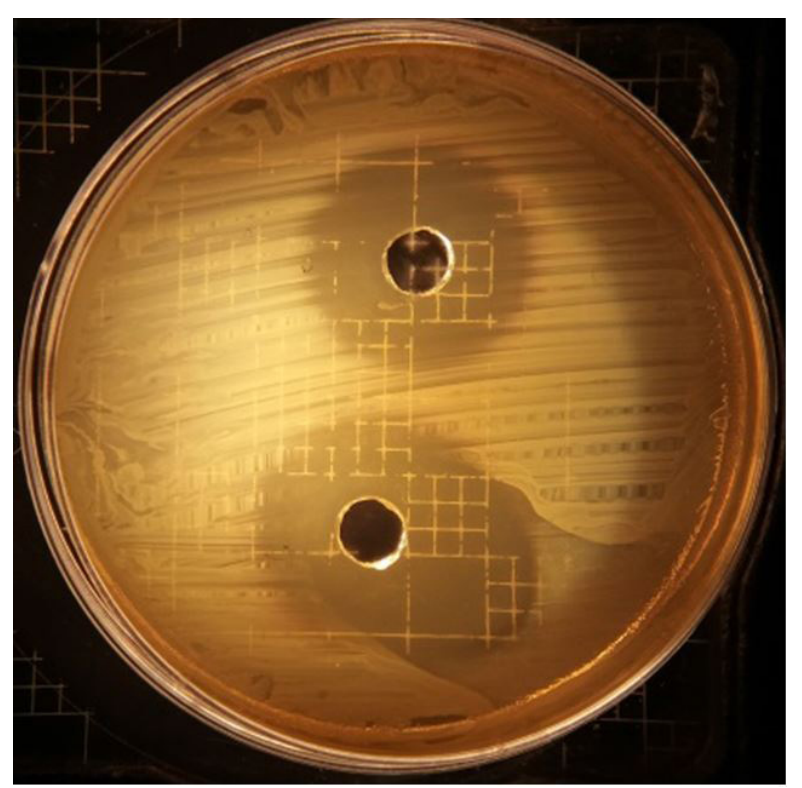

Figure 1. Effect of the citrox solution at a concentration of $1 \%$ and $2 \%$ on methicillin-resistant Staphylococcus aureus.

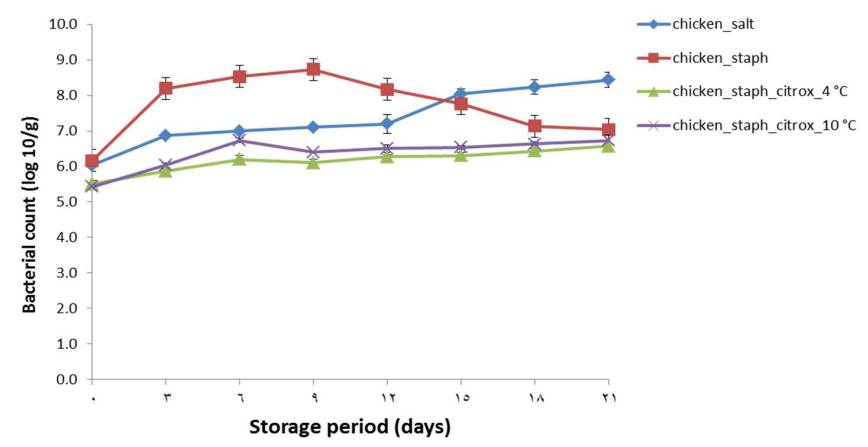

Figure 2. Total viable count of bacteria during storage period at $4{ }^{\circ} \mathrm{C}$. 
and $8.733 \log \mathrm{CFU} / \mathrm{g}$ after 3 and 9 days of the storage period, respectively, exceeding the maximum limit. However, in the chicken samples treated with $0.85 \% \mathrm{NaCl}$ (the negative control), the total count was found to be increased gradually from $7.200 \mathrm{log}$ $\mathrm{CFU} / \mathrm{g}$ on the $12^{\text {th }}$ day to $8.433 \log \mathrm{CFU} / \mathrm{g}$ on the $21^{\text {st }}$ day of storage. The group $\mathrm{C}$ and $\mathrm{D}$ samples stored at $4{ }^{\circ} \mathrm{C}$, revealed a stable TVC of 6.733 and $6.567 \mathrm{log}$ CFU/g, after 21 days of the storage period, respectively that did not exceed the permissible limit. The samples were retained their temperament and were devoid their manifestations of corruption found in the treated samples through all storage period. The TVC in samples treated with $2 \%$ citrox revealed a reduction by 2.5 and 2.0 log cycles as compared to the negative and positive control, respectively, indicating the significant effect of citrox on the bacteria. Moreover, the temperature of domestic and retail store refrigerators, which are considered critical points of the cold chain, often range from -1 to $15^{\circ} \mathrm{C}$ (Bovill et al., 2001; James et al., 2008). Temperature is one of the most important factors that affect microbial growth (Nedwell, 1999; Smolander et al., 2004; Karadag \& Puhakka, 2010). Therefore, the microbial community changes according to varying temperatures (Karadag \& Puhakka, 2010; Franciosi et al., 2011). There are many objective tests suggested to be proving as meat spoilage. According to the standardization organization for G.C.C (GSO), 2007, the maximum limit of the microbial count is $10^{7}-\log \mathrm{CFU} / \mathrm{g}$. Similarly, the permissible limit of TVC by ICMSF, 1986 is $\log 10^{7}$ (for raw chicken, fresh or frozen).

\subsection{Total volatile basic nitrogen}

TVBN, a product of microbial amino acid decarboxylase activity, is used to estimate the shelf life of chicken meat. In the present study as shows in Figure 3, after 21 days of storage, the TVBN values in chicken treated with $1 \%$ and $2 \%$ citrox were $48.067 \mathrm{mg} / 100 \mathrm{~g}$ and $35.933 \mathrm{mg} / 100 \mathrm{~g}$ at $4{ }^{\circ} \mathrm{C}$, respectively. This was significantly lower as compared to chicken breast fillet treated with salt as a negative control (99.867 mg/100 g) and S. aureus (MRSA) as a positive control $(62.533 \mathrm{mg} / 100 \mathrm{~g})$. The TVBN values of citrox treated chicken do not exceed the recommended limit of $60 \mathrm{mg} / 100 \mathrm{~g}$ (NF V 01-003, 2004), during the entire storage period of 21 days and the treatment with the $2 \%$ citrox was better than $1 \%$ citrox. For the treatment of chicken breast fillet when stored at $4^{\circ} \mathrm{C}$ and under vacuum and more effective against MRSA S. aureus and lead to the reduction in the loss of chicken meat quality and improved the safety of it. The chemical method used for determination of spoilage of chicken and the chicken product is the total volatile base nitrogen (TVBN), which serves as an indicator to its quality and safety. Generally, consumers throughout the world do not prefer foods treated with various chemical additives; instead, the demand for natural products being used as preservatives is increasing day by day. Citrox constituted by ingredients of plant origin (citric, ascorbic and malic acid) can be used as an alternative as it is effective in the presence of organic matter, breaks down biofilm, extends shelf life, reduces pathogenic attack, can be applied directly to food as an additive, and conforms to BS EN 1276 (European Suspension Test). Several studies also reported TVBN to be an indicator of the quantity of biogenic amines, which are produced in the microbiological contamination of foods (Min et al., 2004; Min et al., 2007; Vinci \& Antonelli, 2002). The TVBN values of duck/pork meat samples ranged from 124.2 to $172.8 \mathrm{mg} \mathrm{N} / 100 \mathrm{~g}$ during refrigerated storage for 4 weeks (Choe et al., 2017)

\section{$3.3 \mathrm{pH}$ Value}

In the first three days of the experiment, no statistical variance in the $\mathrm{pH}$ was detected for the four groups (Figure 4). The initial $\mathrm{pH}$ of chicken samples treated with salt was 6.010 and reached to 6.650 after 21 days of storage period. Chicken samples treated with $1 \%$ and $2 \%$ citrox had an initial $\mathrm{pH}$ of 6.00 that reached 6.433 and 6.400 , respectively, on the $21^{\text {st }}$ day. High pretentious food that was stored under vacuum such as chicken show an increased $\mathrm{pH}$ because of the number of microorganisms that cause spoilage (Krizek et al., 2004; Balamatsia et al., 2006; Ntzimani et al., 2008). The relative increase in $\mathrm{pH}$ of salt treated chicken as compared to the MRSA treated chicken could be attributed to this fact. The proteolytic activity of mixed microorganisms in a basic compound (Vinci \& Antonelli, 2002), leads to an increase in $\mathrm{pH}$ more as compared to that of one type of bacteria. Chicken treated with $1 \%$ and $2 \%$ citrox solution also showed increased $\mathrm{pH}$ but less than salt and MRSA $S$. aureus treatments. del Río et al. (2007) reported that dipping the chicken meat in citric acid significantly decreased the $\mathrm{pH}$ after marination. Reduction of the $\mathrm{pH}$ value of meat products is considered to influence many factors during the storage period, such as extended storage period, the stability of water binding capacity and texture, and loss of redness (Sammel \& Claus, 2003). Khare et al. (2016), were used a coating solution which was prepared by adding carrageenan and potassium chloride, cinnamon oil and with or without citric acid.

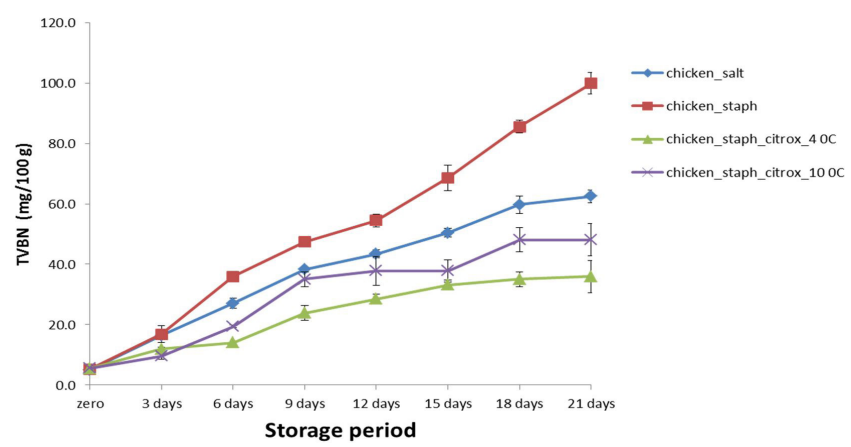

Figure 3. Total volatile base nitrogen during storage period at $4{ }^{\circ} \mathrm{C}$.

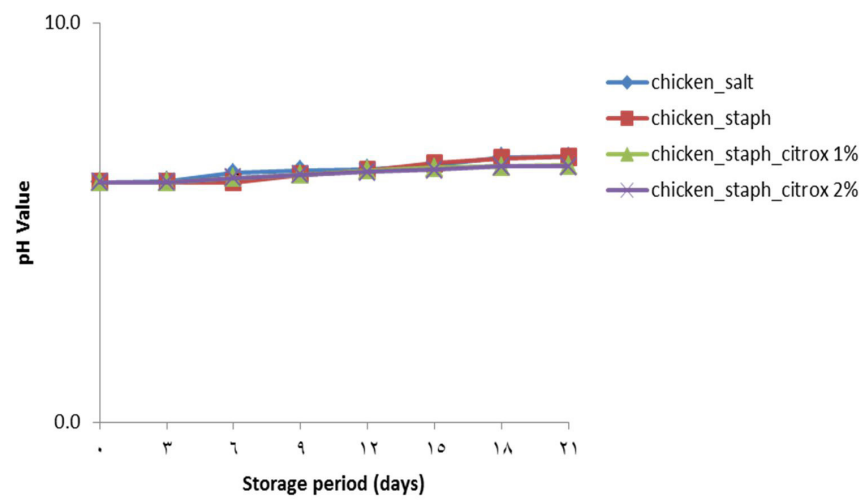

Figure 4. $\mathrm{pH}$ values of chicken samples during storage at $4{ }^{\circ} \mathrm{C}$. 
They noticed that $\mathrm{pH}$ of the coating solution were 7.56 (without citric acid) and citric acid incorporated coating solution had $\mathrm{pH}$ of 3.88-4. However, Petrou et al. (2012), observed no significant difference in $\mathrm{pH}$ of chicken fillets dipped in chitosan and oregano oil throughout storage period.

\subsection{Instrumental color value}

Color differentials of chicken breast fillet treated of the four groups observed in the present study are shown in (Table 1). Significantly higher $\mathrm{L}^{*}$ values were observed for groups $\mathrm{C}$ and $\mathrm{D}$ treated with $1 \%$ and $2 \%$ citrox solution as compared to both the negative and positive control at 9 days of storage. Whereas no significant changes in the $\mathrm{L}^{*}$ value was observed between the negative control and the positive control. A significant increase in the $\mathrm{a}^{*}$ value was observed after 9 days of storage in the sample treated with Staph (group B) as compared to the remaining three groups.

Generally, the reduction in the red color of chicken breast fillet samples during storage period was due to the correlation between lipid and pigment oxidation in meat. This result could be because of the binding of the heme iron of myoglobin with citric acid or the prevention of the formation of pink pigments by acidification (Kieffer et al., 2000). Kim et al. (2015), were stated that chicken breasts group which were treated with citric acid reduced redness when compared to both internal and external redness of control group $(\mathrm{p}<0.05)$.

However, a significant increase in the $\mathrm{b}^{*}$ value was detected in samples treated only with S. aureus MRSA (Chicken- salt- Staph.), than the other three treatments. The effect of chilling and using a various concentration of citrox (acidic) leads to a change of the skin color of chicken breast fillet.

Organic acids present in citrox solution (citric, malic, ascorbic acids) increased lightness and decreased redness and yellowness values. These results are in agreements with Bilgili et al. (1998), who reported that propionic acid had little effect on lightness and redness values, but decreased yellowness values significantly. The lower $a *$ values when used propionic acid treatments of chicken may be due to the oxidizing property of the antimicrobial, but not negatively affecting the sensory attributes (Chen et al., 2014). Similarly, the processing conditions, such as scalding temperature and storage period (Heath \& Thomas, 1973, 1974; McKee et al., 2008; Jeong et al., 2011), pH (Heath \& Wabeck, 1975), and immersion chilling (Lyon \& Cason, 1995), have been shown to affect broiler skin color. Some studies reported that the use of appropriate amounts of lactic acid is important to determine the effect on the fresh and cooked color of meat (Kotula \& Thelappurate, 1994). Lactic acid concentrations of $1.2 \%$ and $1.5 \%$ caused color deterioration in beef samples during display (Kotula \& Thelappurate, 1994). The use of appropriate amounts of lactic acid is important to determine the effect on the fresh and cooked color of meat (Alahakoon et al., 2014). Kim et al. (2015) stated that dipping in citric acid solution was proven to prevent the redness in meat products conferred by the sous-vide process. The increase in CA concentration had a positive influence on the reduction of the pink color by inducing the thermal denaturation of myoglobin during refrigerated storage.

\subsection{Sensory evaluation}

Sensory analysis of the chicken breast samples revealed that the sample injected with MRSA, resulted in lower sensory scores for all parameters compared to control (Table 2). The addition of $1 \%$ and $2 \%$ citrox acquired moderate sensory scores for color, odor, and flavor but lower in taste and tenderness. The use of citrox that contained a combination of flavorings and antioxidants could improve the nutritional and sensory attributes. However, further studies are required to obtain such benefits without compromising microbial safety.

Table 1. Hunter L, a, b color values of chicken breast meat samples treated with $1 \%$ and $2 \%$ citrox and stored at $4{ }^{\circ} \mathrm{C}$ for 21 days.

\begin{tabular}{|c|c|c|c|c|c|c|c|c|c|c|}
\hline \multirow{2}{*}{$\begin{array}{r}\text { Hunter color } \\
\mathbf{L}^{*} \text { (Lightness) }\end{array}$} & \multirow[t]{2}{*}{ Treatment } & \multicolumn{9}{|c|}{ Storage period $(\mathrm{d})$} \\
\hline & & 0 & 3 & 6 & 9 & 12 & 15 & 18 & 21 & Mean $^{1}$ \\
\hline & Chicken - salt (Control) & 50.56 & 51.02 & 51.53 & 51.89 & 52.36 & 49.43 & 48.55 & 47.53 & $50.357^{a}$ \\
\hline & Chicken- salt- Staph & 50.62 & 52.22 & 53.66 & 52.67 & 53.16 & 49.72 & 47.47 & 47.11 & $50.825^{b}$ \\
\hline & Chicken - Staph- Citrox 2\% & 49.37 & 51.41 & 52.46 & 65.33 & 53.09 & 49.61 & 48.41 & 48.14 & $52.227^{c}$ \\
\hline & Mean $^{2}$ & $50.260^{d}$ & $51.827^{\mathrm{e}}$ & $53.075^{f}$ & $59.253^{h}$ & $53.551^{\mathrm{g}}$ & $50.133^{c}$ & $48.669^{b}$ & $48.195^{a}$ & - \\
\hline \multirow{3}{*}{$a^{\star}$ (Redness) } & Chicken - Staph- Citrox 1\% & 0.950 & 1.165 & 2.345 & 5.385 & 0.555 & 0.260 & 0.125 & 0.110 & $1.361^{\mathrm{d}}$ \\
\hline & Chicken - Staph- Citrox 2\% & 1.817 & 2.070 & 3.877 & 6.603 & 1.767 & 1.437 & 1.050 & 0.810 & $2.428^{c}$ \\
\hline & Mean $^{2}$ & $1.289^{\mathrm{e}}$ & $2.278^{c}$ & $3.395^{b}$ & $5.630^{\mathrm{a}}$ & $2.330^{c}$ & $1.512^{\mathrm{d}}$ & $1.330^{\mathrm{e}}$ & $1.200^{f}$ & - \\
\hline \multirow[t]{2}{*}{$\mathbf{b}^{\star}$ (Yellowness) } & Chicken - salt (Control) & 6.380 & 7.710 & 7.525 & 7.460 & 6.580 & 6.140 & 4.485 & 4.265 & $6.318^{b}$ \\
\hline & Chicken- salt- Staph & 4.995 & 5.325 & 9.680 & 9.475 & 9.335 & 14.730 & 11.375 & 11.010 & $9.491^{\mathrm{d}}$ \\
\hline
\end{tabular}

$\mathrm{L}^{*}=$ indicates lightness; $\mathrm{a}^{*}=$ indicates redness; $\mathrm{b}^{*}=$ indicates yellowness. ${ }^{\mathrm{a}, \mathrm{b}}$ means in the same row. 
Yehia et al.

Table 2. Sensory scores of chicken breast meat samples treated with $1 \%$ and $2 \%$ citrox.

\begin{tabular}{lcccccc}
\hline \multicolumn{1}{c}{ Treatments } & Color & Odor & Flavor & Taste & tenderness & Overall acceptability \\
\hline Chicken - salt (Control) & $5.33^{\mathrm{a}}$ & $4.99^{\mathrm{ay}}$ & $5.5^{\mathrm{a}}$ & $5.60^{\mathrm{a}}$ & $5.0^{\mathrm{a}}$ & $5.66^{\mathrm{a}}$ \\
Chicken - salt - Staph & $3.71^{\mathrm{b}}$ & $2.36^{\mathrm{by}}$ & $2.88^{\mathrm{b}}$ & $2.55^{\mathrm{b}}$ & $3.99^{\mathrm{b}}$ & $2.66^{\mathrm{b}}$ \\
Chicken - Staph - Citrox 1\% & $5.10^{\mathrm{ab}}$ & $4.55^{\mathrm{ab}}$ & $4.50^{\mathrm{b}}$ & $4.02^{\mathrm{b}}$ & $4.1^{\mathrm{b}}$ & $3.49^{\mathrm{b}}$ \\
Chicken - Staph - Citrox 2\% & $5.10^{\mathrm{ab}}$ & $4.93^{\mathrm{ab}}$ & $4.80^{\mathrm{b}}$ & $4.75^{\mathrm{b}}$ & $4.2^{\mathrm{b}}$ & $4.00^{\mathrm{b}}$ \\
Mean & 4.81 & 4.207 & 4.42 & 4.23 & 4.322 & 39.525 \\
\hline
\end{tabular}

9 - Point hedonic scale ( 9 = Like extremely, 4-5 = Like moderately, 1 = Dislike extremely) used for all sensory parameters. ${ }^{\text {a,b }}$ Values with different letters within the same column differ significantly $(\mathrm{p}<0.05)$.

The addition of citrus extract $(0.1 \mathrm{~mL} / 100 \mathrm{~g})$, which were used singly or in combination with an oxygen absorber reduced the TVC of aerobically packaged ground chicken meat by 0.5 and $1.5 \log \mathrm{CFU} / \mathrm{g}$, respectively (Mexis et al., 2012). Vardaka et al. (2016) combined citric extract and chitosan $(\mathrm{CH})$ to the turkey meat to improve its taste and odor, and their results were in agreement with the findings of Petrou et al. (2012), who reported that chitosan, applied either singly or in combination with oregano EO, did not negatively influence the taste of chicken breast meat. Both chitosan and Citrox were sensorially acceptable when added to turkey samples, with chitosan characterized by spicy, fruity, and oriental flavors and citrox characterized by a citrus-like flavor. Moreover, the addition of both citrus extract and chitosan may provide the possibility of new flavors and options for poultry products. However, further sensory tests are needed to examine this possibility (Vardaka et al., 2016).

\section{Conclusion}

The results of our study explained the importance of using citrox solution to extend the shelf life of chicken breast fillet samples about 21 days when stored under vacuum at $4{ }^{\circ} \mathrm{C}$. Being a natural compound containing high antioxidant and antibacterial activity, it was able to control MRSA growth on chicken meat. Citrox also improved the sensory characterization of chicken breast fillet samples.

\section{Acknowledgements}

The authors would like to extend their sincere appreciation to the Deanship of Scientific Research at King Saud University for funding this research through Research Group Project No. RG-1435- 016.

\section{References}

Alahakoon, A. U., Jayasena, D. D., Jung, S., Kim, H. J., Kim, S. H., \& Jo, C. (2014). Antimicrobial effect of calcium chloride alone and combined with lactic acid injected into chicken breast meat. Han-gug Chugsan Sigpum Hag-hoeji, 34(2), 221-229. http://dx.doi. org/10.5851/kosfa.2014.34.2.221. PMid:26760942.

Andrew, E.W., Tania, C., Jordan, B., Cindy, M.L., Lindsey, W., Kimberly, P., Jeffrey, T.F., Jolene, B., Elizabeth, M.D, David M.E., Paul S.K., \& Lance B. P. (2011). Multidrug-Resistant Staphylococcus aureus in US Meat and Poultry. Clinical Infection Diseases, 52(10), 1227-1230.

Association of Official Analytical Chemists - AOAC. (1990). Official methods of analysis of association of official analytical chemists (3rd ed). Washington: AOAC. Retrieved from https://law.resource.org/ pub/us/cfr/ibr/002/aoac.methods.1.1990.pdf
Balamatsia, C. C., Paleologos, E. K., Kontominas, M. G., \& Savvaidis, I. N. (2006). Correlation between microbial flora, sensory changes and biogenic amines formation in fresh chicken meat stored aerobically or under modified atmosphere packaging at $4{ }^{\circ} \mathrm{C}$ : Possible role of biogenic amines as spoilage indicators. Antonie van Leeuwenhoek, 89(1), 9-17. http://dx.doi.org/10.1007/s10482-005-9003-4. PMid:16528580.

Bilgili, S. F., Conner, D. E., Pinion, J. L., \& Tamblyn, K. C. (1998). Broiler skin color as affected by organic acids: influence of concentration and method of application. Poultry Science, 77(5), 751-757. http:// dx.doi.org/10.1093/ps/77.5.752. PMid:9603365.

Boost, M. V., O’Donoghue, M. M., \& James, A. (2013). Prevalence of Staphylococcus aureus carriage among dogs and their owners. Epidemiology and Infection, 136(7), 953-964. http://dx.doi.org/10.1017/ S0950268807009326. PMid:17678561.

Bovill, R. A., Bew, J., \& Baranyi, J. (2001). Measurements and predictions of growth for Listeria monocytogenes and Salmonella during fluctuating temperature: II. Rapidly changing temperatures. International Journal of Food Microbiology, 67(1-2), 131-137. http://dx.doi.org/10.1016/ S0168-1605(01)00446-9. PMid:11482561.

Boziaris, I. S., Kordila, A., \& Neofitou, C. (2011). Microbial spoilage analysis and its effect on chemical changes and shelf life of Norway lobster (Nephrops norvegicus) stored in air at various temperatures. International Journal of Food Science \& Technology, 46(4), 887-895. http://dx.doi.org/10.1111/j.1365-2621.2011.02568.x.

Centers for Disease Control and Prevention - CDC. (2013). Antibiotic Resistance Threats in the United States, 2013. Atlanta: CDC. Retrieved from http://www.cdc.gov/drugresistance/threat-re port-2013/

Chen, X., Bauermeister, L. J., Hill, G. N., Singh, M., Bilgili, S. F., \& McKee, S. R (2014). Efficacy of various antimicrobials on reduction of Salmonella and Campylobacter and quality attributes of ground chicken obtained from poultry parts treated in a post-chill decontamination tank. Journal of Food Protection, 77(11), 1882-1888. http://dx.doi. org/10.4315/0362-028X.JFP-14-114. PMid:25364921.

Choe, J., Brad Kim, Y. H., Kim, H. Y., \& Kim, C. J. (2017). Evaluations of physicochemical and anti-oxidant properties of powdered leaves from lotus, shepherd's purse and goldenrod in restructured duck/pork patties. Journal of Food Science and Technolology, 54(8): 2494-2502.

Cuny, C., Wieler, L. H., \& Witte, W. (2015). Livestock associated MRSA: The impact on humans. Antibiotics, 4(4), 521-543. http://dx.doi. org/10.3390/antibiotics4040521. PMid:27025639.

de Boer, E., Zwartkruis-Nahuis, J. T., Wit, B., Huijsdens, X. W., de Neeling, A. J., Bosch, T., van Oosterom, R. A., Vila, A., \& Heuvelink, A. E. (2009). Prevalence of methicillin-resistant Staphylococcus aureus in meat. International Journal of Food Microbiology, 134(1-2), 52-56. http://dx.doi.org/10.1016/j.ijfoodmicro.2008.12.007. PMid:19144432.

del Río, E., Muriente, R., Prieto, M., Alonso-Calleja, C., \& Capita, R. (2007). Effectiveness of trisodium phosphate, acidified sodium chlorite, citric acid and peroxy acids against pathogenic bacteria on poultry during refrigerated storage. Journal of Food Protection, 
70(9), 2063-2071. http://dx.doi.org/10.4315/0362-028X-70.9.2063. PMid:17900083.

Deurenberg, R. H., Vink, C., Kalenic, S., Friedrich, A. W., Bruggeman, C. A., \& Stobberingh, E. E. (2007). The molecular evolution of methicillin-resistant Staphylococcus aureus. Clinical Microbiology and Infection, 13(3), 222-235. http://dx.doi.org/10.1111/j.14690691.2006.01573.x. PMid:17391376.

Duncan, D. B. (1955). Multiple range and multiple (F) test. Biometrics, 11(1), 1-45. http://dx.doi.org/10.2307/3001478.

Dweba, C. C., Zishiri, O. T., \& El Zowalaty, M. E. (2019). Isolation and molecular identification of virulence, antimicrobial and heavy metal resistance genes in livestock-associated methicillin-resistant staphylococcus aureus. Pathogens, 8(2), 79. http://dx.doi.org/10.3390/ pathogens8020079. PMid:31207959.

European Food Safety Authority - EFSA. (2009). Analysis of the baseline survey on the prevalence of Methicillin-Resistant Staphylococcus aureus (MRSA) in holdings with breeding pigs, in the EU, 2008, Part A: MRSA prevalence estimates. EFSA Journal, 7, 1376. http:// dx.doi.org/10.2903/j.efsa.2009.1376.

Franciosi, E., Settanni, L., Cologna, N., Cavazza, A., \& Poznanski, E. (2011). Microbial analysis of raw cows' milk used for cheese making: Influence of storage treatments on microbial composition and other technological traits. World Journal of Microbiology \& Biotechnology, 27(1), 171-180. http://dx.doi.org/10.1007/s11274-010-0443-2.

Fraqueza, M. J., Ferreira, M. C., \& Barreto, A. S. (2008). Spoilage of light (PSE-like) and dark turkey meat under aerobic or modified atmosphere package: Microbial indicators and their relationship with total volatile basic nitrogen. British Poultry Science, 49(1), 1220. http://dx.doi.org/10.1080/00071660701821675. PMid:18210285.

Gram, L., \& Dalgaard, P. (2002). Fish spoilage bacteria-problems and solutions. Current Opinion in Biotechnology, 13(3), 262-266. http:// dx.doi.org/10.1016/S0958-1669(02)00309-9. PMid:12180103.

Hasman, H., Moodley, A., Guardabassi, L., Stegger, M., Skov, R. L., \& Aarestrup, F. M. (2010). Spa type distribution in Staphylococcus aureus originating from pigs, cattle and poultry. Veterinary Microbiology, 141(3-4), 326-331. http://dx.doi.org/10.1016/j.vetmic.2009.09.025. PMid:19833458.

Heath, J. L., \& Thomas, O. P. (1973). The xanthophyll content and color of broiler skin after scalding. Poultry Science, 52(3), 967-971. http:// dx.doi.org/10.3382/ps.0520967.

Heath, J. L., \& Thomas, O. P. (1974). The effect of scalding conditions on the xanthophyll content and color of broiler skin. Poultry Science, 53(5), 1880-1885. http://dx.doi.org/10.3382/ps.0531880.

Heath, J. L., \& Wabeck, C. J. (1975). The effect on xanthophyll content and color of broiler skin when scald additive concentration was measured by pH. Poultry Science, 54(4), 1288-1292. http://dx.doi. org/10.3382/ps.0541288.

Hernández-Herrero, M. M., Roig-Sagués, A. X., López-Sabater, E. I., Rodríguez-Jerez, J. J., \& Mora-Ventura, M. T. (1999). Influence of storage temperature on the quality of beef liver; $\mathrm{pH}$ as a reliable indicator of beef liver spoilage. Journal of the Science of Food and Agriculture, 79, 2035-2039. http://dx.doi.org/10.1002/(SICI)10970010(199911)79:14<2035::AID-JSFA481>3.0.CO;2-I.

James, S. J., Evans, J., \& James, C. (2008). A review of the performance of domestic refrigerators. Journal of Food Engineering, 87(1), 2-10. http://dx.doi.org/10.1016/j.jfoodeng.2007.03.032.

Jeong, J. Y., Janardhanan, K. K., Booren, A. M., Karcher, D. M., \& Kang, I. (2011). Moisture content, processing yield, and surface color of broiler carcasses chilled by water, air, or evaporative air. Poultry
Science, 90(3), 687-693. http://dx.doi.org/10.3382/ps.2010-00980. PMid:21325243.

Karadag, D., \& Puhakka, J. A. (2010). Effect of changing temperature on anaerobic hydrogen production and microbial community composition in an open-mixed culture bioreactor. International Journal of Hydrogen Energy, 35(20), 10954-10959. http://dx.doi. org/10.1016/j.ijhydene.2010.07.070.

Khanna, T., Friendship, R., Dewey, C., \& Weese, J. S. (2008). Methicillin resistant Staphylococcus aureus colonization in pigs and pig farmers. Veterinary Microbiology, 128(3-4), 298-303. http://dx.doi.org/10.1016/j. vetmic.2007.10.006. PMid:18023542.

Khare, A. K., Abraham, R. J. J., Rao, V. A., \& Babu, R. N. (2016). Utilization of carrageenan, citric acid and cinnamon oil as an edible coating of chicken fillets to prolong its shelf life under refrigeration conditions. Veterinary World, 9(2), 166-175.

Kieffer, K. J., Claus, J. R., \& Wang, H. (2000). Inhibition of pink color development in cooked uncured ground turkey by the addition of citric acid. Journal of Muscle Foods, 11(3), 235-243. http://dx.doi. org/10.1111/j.1745-4573.2000.tb00428.x.

Kim, J. H., Hong, G. E., Lim, K. W., Park, W., \& Lee, C. H. (2015). Influence of citric acid on the pink color and characteristics of sous vide processed chicken breasts during chill storage. Han-gug Chugsan Sigpum Hag-hoeji, 35(5), 585-596. http://dx.doi.org/10.5851/ kosfa.2015.35.5.585. PMid:26761885.

Krizek, M., Vácha, F., Vorlová, L., Lukásová, J., \& Cupákova, S. (2004). Biogenic amines in vacuum-packed and non-vacuum-packed flesh of carp (Cyprinus carpio) stored at different temperatures. Food Chemistry, 88(2), 185-191. http://dx.doi.org/10.1016/j.foodchem.2003.12.040.

Kotula, K. L., \& Thelappurate, R. (1994). Microbiological and sensory attributes of retail cuts of beef treated with acetic and lactic acid solutions. Journal of Food Protection, 57(8), 665-670. http://dx.doi. org/10.4315/0362-028X-57.8.665. PMid:31121755.

Lyon, C. E., \& Cason, J. A. (1995). Effect of water chilling on objective color of bruised and unbruised broiler tissue. Poultry Science, 74(11), 1894-1899. http://dx.doi.org/10.3382/ps.0741894.

McKee, S. R., Townsend, J. C., \& Bilgili, S. F. (2008). Use of a scald additive to reduce levels of Salmonella Typhimurium during poultry processing. Poultry Science, 87(8), 1672-1677. http://dx.doi. org/10.3382/ps.2008-00061. PMid:18648065.

Mexis, S. F., Chouliara, E., \& Kontominas, M. G. (2012). Shelf life extension of ground chicken meat using an oxygen absorber and a citrus extract. LWT - Food Science and Technology, 49(1), 21-27. https://doi.org/10.1111/j.1365-2621.2012.03162.x

Min, J. S., Lee, S. O., Jang, A., Jo, C., Park, C. S., \& Lee, M. (2007). Relationship between the concentration of biogenic amines and volatile basic nitrogen in fresh beef, pork, and chicken meat. AsianAustralasian Journal of Animal Sciences, 20(8), 1278-1284. http:// dx.doi.org/10.5713/ajas.2007.1278.

Min, J. S., Lee, S. O., Jang, A., Lee, M., \& Kim, Y. (2004). Production of biogenic amines by microflora inoculated in meats. AsianAustralasian Journal of Animal Sciences, 17(10), 1472-1478. http:// dx.doi.org/10.5713/ajas.2004.1472.

Nedwell, D. B. (1999). Effect of low temperature on microbial growth: Lowered affinity for substrates limits growth at low temperature. FEMS Microbiology Ecology, 30(2), 101-111. http://dx.doi. org/10.1111/j.1574-6941.1999.tb00639.x. PMid:10508935.

Nemati, M., Hermans, K., Lipinska, U., Denis, O., Deplano, A., Struelens, M., Devriese, L. A., Pasmans, F., \& Haesebrouck, F. (2008). Antimicrobial resistance of old and recent Staphylococcus aureus isolates from poultry: first detection of livestock associated methicillin-resistant 
strain ST398. Antimicrobial Agents and Chemotherapy, 52(10), 38173819. http://dx.doi.org/10.1128/AAC.00613-08. PMid:18663024.

Ntzimani, A. G., Paleologos, E. K., Savvaidis, I. N., \& Kontominas, M. G. (2008). Formation of biogenic amines and relation to microbial flora and sensory changes in smoked turkey breast fillets stored under various packaging conditions at $4{ }^{\circ} \mathrm{C}$. Food Microbiology, 25(3), 509517. http://dx.doi.org/10.1016/j.fm.2007.12.002. PMid:18355676.

Petrou, S., Tsiraki, M., Giatrakou, V., \& Savvaidis, I.N. (2012). Chitosan dipping or oregano oil treatments, singly or combined on modified atmosphere packaged chicken breast meat. International Journal of Food Microbiology, 156(3), 264-271. https://doi.org/10.1016/j. ijfoodmicro.2012.04.002

Rossolini, G. M., Arena, F., Pecile, P., \& Pollini, S. (2014). Update on the antibiotic resistance crisis. Current Opinion in Pharmacology, 18, 56-60. http://dx.doi.org/10.1016/j.coph.2014.09.006. PMid:25254623.

Sammel, L. M., \& Claus, J. R. (2003). Citric acid and sodium citrate effects on reducing pink color defect of cooked intact turkey breast and ground turkey rolls. Journal of Food Science, 68(3), 874-878. http://dx.doi.org/10.1111/j.1365-2621.2003.tb08259.x.

SAS Institute Inc. (1988). SAS/STAT user's guide. Release 6.03. Cary, NC: SAS Inst.

Smith, T. C., Male, M. J., Harper, A. L., Kroeger, J. S., Tinkler, G. P., Moritz, E. D., Capuano, A. W., Herwaldt, L. A., \& Diekema, D. J. (2009). Methicillin-Resistant Staphylococcus aureus (MRSA) strain ST398 is present in midwestern U.S. swine and swine workers. Plos One, 4(1), 1-6. https://doi.org/10.1371/journal.pone.0004258

Smittle, R. (2000). Microbiological safety of mayonnaise, salad dressings, and sauces produced in the united states: a review. Journal of Food Protection, 63(8), 1144-1153. http://dx.doi.org/10.4315/0362028X-63.8.1144. PMid:10945595.

Smolander, M., Alakomi, H. L., Ritvanen, T., Vainionpää, J., \& Ahvenainen, R. (2004). Monitoring of the quality of modified atmosphere-packaged broiler chicken cuts stored in different temperatures conditions. A time-temperature indicators as quality indicating tools. Food Control, 15(3), 217-229. http://dx.doi.org/10.1016/S0956-7135(03)00061-6.

Sofos, J. N., \& Geornaras, I. (2010). Overview of current meat hygiene and safety risks and summary of recent studies on biofilms, and control of Escherichia coli O157:H7 in nonintact, and Listeria monocytogenes in ready-to-eat, meat products. Meat Science, 86(1), 2-14. http:// dx.doi.org/10.1016/j.meatsci.2010.04.015. PMid:20510532.

Vardaka, V. D., Yehia, H. M., \& Savvaidis, I. N. (2016). Effects of Citrox and chitosan on the survival of Escherichia coli O157:H7 and Salmonella enterica in vacuum-packaged turkey meat. Food Microbiology, 58, 128-134.

Vasilatos, G. C., \& Savvaidis, I. N. (2013). Chitosan or rosemary oil treatments, singly or combined to increase turkey meat shelf-life. International Journal of Food Microbiology, 166(1), 54-58. http:// dx.doi.org/10.1016/j.ijfoodmicro.2013.06.018. PMid:23827808.

Vinci, G., Antonelli, M. L. (2002). Biogenic amines: Quality index of freshness in red and white meat. Food Control, 13, 519-524.

Vincze, S., Stamm, I., Kopp, P.A., Hermes, J., Adlhoch, C., Semmler, T., Wieler, L.H., Lubke-Becker, A., \& Walther, B. (2014). Alarming proportions of Methicillin-Resistant Staphylococcus aureus (MRSA) in wound samples from companion animals, Germany 2010-2012. Plos One, 9, 1-6.

Wendlandt, S., Schwarz, S., \& Silley, P. (2013). Methicillin resistant Staphylococcus aureus: a food-borne pathogen? Annual Review of Food Science and Technology, 4(1), 117-139. http://dx.doi.org/10.1146/ annurev-food-030212-182653. PMid:23190141.

Wong, J. W. H., Ip, M., Tang, A., Wei, V. W. I., Wong, S. Y. S., Riley, S., Read, J. M., \& Kwok, K. O. (2018). Prevalence and risk factors of community-associated methicillin resistant Staphylococcus aureus carriage in Asia-Pacific region from 2000 to 2016: a systematic review and meta-analysis. Clinical Epidemiology, 10, 1489-1501. http://dx.doi.org/10.2147/CLEP.S160595. PMid:30349396. 